\title{
FUNCTIONAL DEVELOPMENT OF SMALL INTESTINE OF JAPANESE QUAIL HATCHED ON MIR ORBITAL STATION
}

\author{
LENHARDT, L. ${ }^{1}$, CIGÁNKOVÁ, V. ${ }^{1}$, ZIBRÍN, M. ${ }^{1}$, KOČIŠOVÁ, J. ${ }^{1}$, TOMKOVÁ, I. ${ }^{1}$, SABO, V. ${ }^{2}$ \\ BOĎA, K. ${ }^{3}$, DADASHEVA, O. A. ${ }^{4}$, GURIEVA, T. S. ${ }^{4}$, MOZEŠ, Š.$^{5}$ \\ ${ }^{1}$ University of Veterinary Medicine, Košice, Slovak Republic; ${ }^{2}$ Institute of Animal Biochemistry and Genetics, \\ Slovak Academy of Sciences, Ivanka pri Dunaji, Slovak Republic; ${ }^{3}$ Research Institute of Veterinary Medicine, \\ Ivanka pri Dunaji, Slovak Republic; \\ ${ }^{4}$ State Scientific Centre - Institute for Biomedical Problems, Moscow, Russia; \\ ${ }^{5}$ Institute of Animal Physiology, Slovak Academy of Sciences, Košice, Slovak Republic
}

Received December 12, 2000

Accepted May 28, 2001

\section{Abstract}

Lenhardt L., V. Cigánková, M. Zibrín, J.Kočišová, I. Tomková, V. Sabo, K. Boda, O. A. Dadasheva, T. S. Gurieva, Š. Mozeš: Functional Development of Small Intestine of Japanese Quail Hatched on Mir Orbital Station. Acta vet. Brno 2001, 70: 127-131.

The effect of microgravity on functional development of the small intestine of Japanese quails incubated for 2-3 d and hatched on the orbital station MIR was examined. After $5 \mathrm{~d}$ of space flight duodenal and jejunal alkaline phosphatase (AP) activity of the experimental group was compared with the AP activity in quails of the same age hatched on the Earth (laboratory controls). Shortterm microgravity leading to decreased food intake resulted in significant increase of AP activity in both duodenal and jejunal enterocytes $(P<0.001)$ of the experimental quails. The results suggest that increased AP activity probably reflects the delayed functional development of the small intestine as a consequence of inapropriate food intake during non-physiological conditions of space flight.

Microgravity, posthatch quail, alkaline phosphatase, food intake, fasting

The replenishment of human food supply is a principal question for a long-term space mission. The prolonged space flight conditions on orbital complexes require a closed ecosystem in which the plant biomass is transformed to high quality proteins. The effect of a weightless environment has been extensively studied on the animal model of Japanese quail that has been compared other birds proposed as more efficient converters of feed to meat and eggs (Meleshko et al. 1993). It was observed that after a short-term space flight adult quails displayed only reversible ultrastructural changes in the tissues of the skeletal muscle, testes and kidneys (Kočišová et al. 1993; Cigánková et al. 1993), and the microstructure of the small intestine as well as spontaneous feeding of the birds were not seriously impaired (Kočišová et al. 1993; Koštál et al. 1993). On the other hand, nonphysiological conditions of space flight during embryogenesis lead to a lower hatching rate, higher frequency of deviations in organ and brain development (Dadasheva and Guryeva 1993; Guryeva et al. 1993; Lychakov et al. 1993), and to disturbances in the locomotor activity and in consequence in inability to feed properly after hatching in these quails (B od’a et al. 1991; Koštál et al. 1993).

Embryonic and early post-hatch development of the birds is a period with rapid morphological and functional development of the gastrointestinal tract (Baranyiová 1972). Changes in nutrition from the first day after hatching when the yolk sac rich in lipids is progressively replaced in the birds by a solid diet rich in carbohydrates (Buddington and Diamond 1989) are also related to morphological (B aranyiová and Holman 1976; Uni et al. 1995) and enzymatic changes in the small intestine (Uni et al. 1998). Among the

Address for correspondence:

MVDr. Štefan Mozeš, PhD

MVDr. Stefan Mozeš, PhD
Institute of Animal Physiology, SAV
Šoltésovej 4

Phone:

04001 Košice. Slovak Republic

Fax: 42195762162

E-mail: mozes@ saske.sk
http://www.vfu.cz/acta-vet/actavet.htm 
enzymes of the small intestine alkaline phosphatase (AP) is a representative brush border enzyme functionally involved in the active uptake of nutrients (Takase and Goda 1990; Bernard et al. 1992) and has been considered to be an enterocyte maturation marker (Weiser 1973; Henning 1981).

The morphological and functional evolution of the small intestine has been well documented in intact embryonic (Moog 1950) and posthatch chicks (Baranyiová 1972; Uni et al. 1998) and poults (Uni et al. 1999). It was also demonstrated that early hormonal disbalances significantly changed the AP activity in chick embryos (Hinni and Watterson 1963; Moog and Richardson 1955) and that food restriction or fasting depressed the development of their intestinal mucosa for several days after hatching (Uni et al. 1998). At present time, however, no information is available about AP in Japanese quails or about the effects of non-physiological factors in relation to space flight on the functional development of their small intestine.

In present study the AP activity in the brush-border of duodenal and jejunal enterocytes of Japanese quails hatched after 2-3 days of incubation and followed by a 5 day- space-flight on the "MIR" orbital station was compared with enzyme activity in animals incubated and hatched on Earth under laboratory conditions.

\section{Materials and Methods}

After transport on orbital station MIR fertilized eggs of quails (Coturnix coturnix japonica) were incubated for 2-3 days at $39-40{ }^{\circ} \mathrm{C}$ (incubator IM-02). The space flight of the hatched quails lasted 5 days. Upon return to Earth, $11 \mathrm{~h}$ after landing, the animals ( 3 cockerels) were sacrificied and samples of the small intestine collected, frozen and stored at $-18{ }^{\circ} \mathrm{C}$ for histochemical analysis. According to approved protocols samples of the duodenum and jejunum were obtained from three quail cockerels of the same age, incubated and hatched on Earth (laboratory controls). On the day of the experiment, a segment of the frozen tissue was cut at $7 \mu \mathrm{m}$ in the cryostat at $-25^{\circ} \mathrm{C}$, and the tissue slices were transported to glass slides and air-dried. From each tissue segment six sections were cut for enzyme assay.

Demonstration of alkaline phosphatase activity was performed using a modified simultaneous azo-coupling method according to Lojda et al. (1979). The incubation medium contained naphthol AS-BI phosphate (Sigma, Deisenhofen, Germany), Fast blue BB (Aldrich, Germany), N.N-dimethylformamide (solvent for naphthol AS-BI phosphate) and veronal acetate buffer ( $\mathrm{pH} 9.2$ ). Incubation was performed at $37{ }^{\circ} \mathrm{C}$ for $10 \mathrm{~min}$, using substrate concentration of $2.0 \mathrm{mM}$ and $\mathrm{pH}$ of 8.9. Enzyme activity was cytophotometrically analysed with a Vickers M85a microdensitometer. The measurements were carried out by means of an $\times 40$ objective, an effective scanning area of $28.3 \mu \mathrm{m}^{2}$ and a scanning spot of $0.5 \mu \mathrm{m}$. The integrated absorbance was measured at a wavelength of $480 \mathrm{~nm}$. The mask was set over at least 30 brush border areas along the villus length (from the cryptal parts to the tip) in the duodenal and jejunal sections. AP activity was calculated as the absorbance values recorded by the instrument in $\mathrm{min} / \mathrm{mm}^{-3}$ brush border \pm SEM.

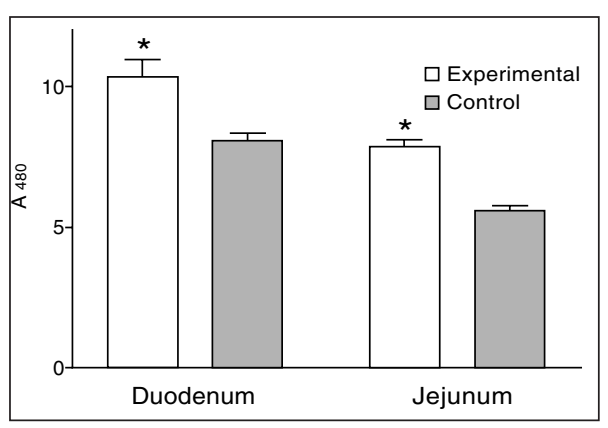

Fig. 1. Alkaline phosphatase activity in duodenal and jejunal enterocytes from experimental and control quails. Values represent the mean \pm S.E.M. of integrated absorbance in $\mathrm{min} / \mu_{\mathrm{m}}{ }^{3}$ brush border of cells at a wavelength of $480 \mathrm{~nm}$. $* p<0.001$ significantly different from the controls.
Statistical evaluation of the results was carried out by one-way analysis of variance (ANOVA). The significance of differences between the control and experimental animals was determined by using Tukey's test.

\section{Results}

Fig. 1 summarizes the AP values in the experimental and control quails. Comparison of the experimental groups with their Earth controls revealed that 5 days after hatching on orbital station the activity of AP was significantly increased as evidenced by $30 \%$ and $45 \%$ higher activity $(p<0.001)$ in duodenal and jejunal enterocytes. Plate I, Fig. 2 and 3 show the AP activity along the villus axis of the jejunum in $7 \mu \mathrm{m}$ cryostat sections. The final reaction product observed in the 
brush border of the jejunal epithelial cell showed a substantially higher activity in quail cockerels exposed to non-physiological conditions of microgravity (Fig. 2) than in the birds hatched on Earth (Fig. 3).

\section{Discussion}

Quantitative histochemical analysis of the brush-border-bound duodenal and jejunal alkaline phosphatase activity studied in the present experiment has provided information about the intestinal function in Japanese quails especially in relation to the effect of microgravity. The results revealed that duodenal and jejunal AP was significantly increased in experimental quails as compared to the Earth controls. The exact mechanism which induces such differences in enzyme activity has not been fully elucidated. It could be speculated whether the short-term incubation, space flight conditions on the orbital station or both may be of importance for the development of such functional changes in the small intestine. It is well-known that the intestinal growth and enzyme development are finely controlled in the embryonal and posthatch birds. Although the intestinal system of the chicks is anatomically complete at the end of embryonic life (Chambers and Grey 1979), with the onset of food intake rapid changes in the dimensions and morphology of the small intestine occurred from day of hatching and continued to grow until 2 weeks (Baranyiová 1972; Baranyiová and Holman 1976; Uni et al. 1998, 1999). However, during this period the mucosal enzymes show different developmental time. In chick embryos the first appearence of AP in the brush border of the duodenum was histochemically demonstrated at $18 \mathrm{~d}$ (Moog 1950). As the development proceeded AP activity increased and reached its maximum during the hatching period and decreased at about 2-4 days after hatch (Uni et al. 1998). In contrast, in poults AP activity increased just prior to hatch but changed only little thereafter (Uni et al. 1999). From this point of view the significantly higher duodenal and jejunal AP activity observed in the experimental quails may be partly explained by the different enzyme development pattern due to non-physiological conditions; however, AP activity has not yet been examined in intact posthatch quails.

In chicks the timing of the first feeding has been shown to be critical for the development of the small intestine (Baranyiová 1972). While feeding stimulated, delayed access to food after hatch for 1 to 5 days depressed the development of the intestinal mucosa (Baranyiová and Holman 1976; Uni et al. 1998). Observations of the intestinal AP indicates that its activity is also directly related to the presence and the amount of food in the alimentary tract. It has been demonstrated that AP activity is closely related to the day-night fluctuation of food intake (Martink ová et al. 2000) and decreased after fasting in neonatal (Baker et al.1987) and adult animals (Majumdar and Panda 1989). On the other hand, food restriction had an opposite effect i.e. it led to increased AP activity (Kelly et al. 1991). It is therefore possible that the increase of AP activity observed in experimental animals may rather be an effect of a simple "over" production of the enzyme relative to amount of food in the gastrointestinal tract than a consequence of fasting. According to this hypothesis, despite problems with spontaneous feeding of the quails during weightlessness (observed from video recordings), their food consumption decreased but did not cease as confirmed the presence of the food in their alimentary tract after $5 \mathrm{~d}$ of space flight (unpublished observations).

Finally, the present experiment extends also our knowledge on the intestinal function in Japanese quail. The results of the experiment have revealed that the significant increase of AP activity in quails hatched on the orbital station may be attributed, at least in part, to the delayed development of the intestinal function which seems to be due to disturbances in food intake during microgravity. However, additional experiments, especially on the reversibility and significance of these functional changes for further development of the quails are needed to clarify this observation. 


\section{Funkčný vývoj tenkého čreva japonských prepelíc vyliahnutých na orbitálnej stanici MIR}

V pokuse bol sledovaný vplyv mikrogravitácie na funkčný vývoj tenkého čreva u japonských prepelíc inkubovaných (2-3) dni a vyliahnutých na orbitálnej stanici MIR. Po 5 dňovom kozmickom lete aktivita alkalickej fosfatázy (AF) $\mathrm{v}$ duodene a jejune experimentálnej skupiny bola porovnávaná s aktivitou enzymu u skupiny rovnako starých kontrolných prepelíc vyliahnutých na Zemi (laboratórna kontrola). Krátkodobá mikrogravitácia spojená so znížením príjmu krmiva viedla k signifikantnému zvýšeniu aktivity AF $\mathrm{v}$ enterocytoch duodena a jejuna experimentálnych zvierat $(P<0.001)$. Výsledky poukazujú na to, že zvýšená aktivita AF pravdepodobne odzrkadluje opozdený funkčný vývoj tráviaceho traktu ako dôsledok nedostatočného príjmu potravy počas nefyziologických podmienok kozmického letu.

\section{References}

BAKER, S. S., SUTHUTVORAVUT, U., WALKER, W. 1987: Short-term malnutrition in neonatal rabbits. I. Brush border enzymes. J. Pediatr. Gastroenterol. Nutr. 6: 961-966

BARANYIOVÁ, E. 1972: Influence of deutectomy, food intake and fasting on the digestive tract dimensions in chickens after hatching. Acta Vet. Brno 41: 373-384

BARANYIOVÁ, E., HOLMAN, J. 1976: Morphological changes in the intestinal wall in fed and fasted chickens in the first week after hatching. Acta Vet. Brno 45: 151-158

BERNARD, A., CASELLI, C., BLOND, J. P., CARLIER, H. 1992: Dietary fatty acid composition, age and rat jejunal microvillus enzyme activity. Comp. Biochem. Physiol. 101: 607-612

BOD̃A, K., MELESHKO, G. I., SABO, V., SHEPELEV, Ye.Ya., GURYEVA, T S., JURÁNI, M., KOŠŤÁL, L. 1991: Embryonic development of Japanese quail under microgravity conditions. Physiologist 34: S59-S61

BUDDINGTON, R. K., DIAMOND, M. J. 1989: Ontogenetic development of intestinal nutrient transporter. Annu. Rev. Physiol. 51: 609-619

CIGÁNKOVÁ, V., KOČIŠOVÁ, J., BOĎA, K., TOMAJKOVÁ, E., DADASHEVA, O. A. 1993: Morphological changes in tissue of the testes and kidneys in Japanse quail exposed to microgravity. Acta Vet. Brno, suppl. 6 , 62: S69-S71

CHAMBERS, C., GREY, R. D. 1979: Development of the structural components of the brush border in absorbtive cells of the chick intestine. Cell. Tiss. Res. 204: 387-405

DADASHEVA, O. A., GURYEVA, T. S. 1993: Bone and muscular tissue development in embryos and newly hatched quail incubated in weighlessness. Acta Vet. Brno, suppl. 6, 62: S51-S59

HENNING, S. J. 1981: Postnatal development: Coordination of feeding, digestion, and metabolism. Am. J. Physiol. 241: G199-G214

GURYEVA, T. S., DADASHEVA, O.A., MELESHKO, G. I., SHEPELEV, Ye. Ya., BOĎA, K., SABO, V. 1993. The quail embryonic development under the conditions of weightlessness. Acta Vet. Brno, suppl. 6, 62: S25$\mathrm{S} 30$

HINNI, J. B., WATTERSON, R. L. 1963: Modified development of the duodenum of chick embryos hypophysectomised by partial decapitation. J. Morphol. 113: 381-426

KELLY, D., SMYTH, J. A., McCRACEN, K. J. 1991: Digestive development of early-weaned pig. 2. Effect of level of food intake on digestive enzyme activity during the immediate post-weaning period. Br. J. Nutr. 65: $181-188$

KOČIŠOVÁ, J., CIGÁNKOVÁ, V., BOĎA, K., TOMAJKOVÁ, E., DADASHEVA, O. A. 1993: Ultrastructure of small intestine enterocytes of Japanese quail after exposure to microgravity. Acta Vet. Brno, suppl. 6, 62: S81 $-\mathrm{S} 82$

KOŠŤÁL, L., JURÁNI, M., BOĎA, K., SHEPELEV, Ye. Ya., GURYEVA, T. S., SABO, V., DADASHEVA, O. A. 1993: Behaviour of Japanese quail in microgravity on the "MIR" orbital station. Acta Vet. Brno, suppl. 6, 62: S65-S67.

LOJDA, Z., GROSSRAU, R., SCHIBLER, T. H. 1979: Enzyme Histochemistry. Springer-Verlag, Berlin, pp. 5970 .

LYCHAKOV, D V. ILINSKAYA, E V ., DADASHEVA, O A , GURYEVA, T S. 1993: Swelling of calyx-like nerve endings in maculae and cristae of quail embryos exposed to weightlessness. Acta Vet. Brno, suppl. 6, 62: $\mathrm{S} 31-\mathrm{S} 34$

MAJUMDAR, S., PANDA, J. N. 1989: The activities of phosphatases and aminotransferases in the epithelium of the small intestine and caecum of White Rock cockerels during starvation. J. Vet. Med. A. 36: 348-353

MARTINKOVÁ, A., LENHARDT, L., MOZEŠ, Š. 2000: Effect of neonatal MSG treatment on day-night alkaline phosphatase activity in the rat duodenum. Physiol. Res. 49: 339-345 
MELESHKO, G. I., GURIEVA, T. S., SHEPELEV Ye. Ya., ABAKUMOVA, I. A. 1993:Quail as a possible object of biological life-support systems of space crews. Acta Vet. Brno, suppl. 6, 62: S9-S15

MOOG, F. 1950: The functional differentiation of the small intestine. The accumulation of alkaline phosphomonoesterase in the duodenum of the chick. J. Exptl. Zool. 115:109- 129

MOOG, F., RICHARDSON, D. 1955: The functional differentiation of the small intestine. IV. The influence of adrenocortical hormones on differentiation and phosphatase synthesis in the duodenum of the chick embryo. J. Exptl. Zool. 130: 29-56

UNI, Z., NOY, Y., SKLAN, D. 1995: Posthatch changes in morphology and function of the small intestines in heavy- and light-strain chicks. Poultry Sci.74: 1622-1629

UNI, Z., GANOT, S., SKLAN, D. 1998: Posthatch development of mucosal function in the broiler small intestine. Poultry Sci. 77: 1998: $75-82$

UNI, Z., NOY, Y., SKLAN, D. 1999: Posthatch development of small intestinal function in the poult. Poultry Sci. 78: $215-222$

TAKASE, S., GODA, T. 1990: Effects of medium-chain triglycerides on brush border membrane-bound enzyme activity in rat small intestine. J. Nutr. 120: 969-976

WEISER, M. M. 1973: Intestinal epithelial cell surface membrane glycoprotein synthesis.I. An indicator of cellular differentiation. J. Biol. Chem. 248: 2536-2541 
Plate I

Lenhardt L. et al.: Functional...pp. 127-131

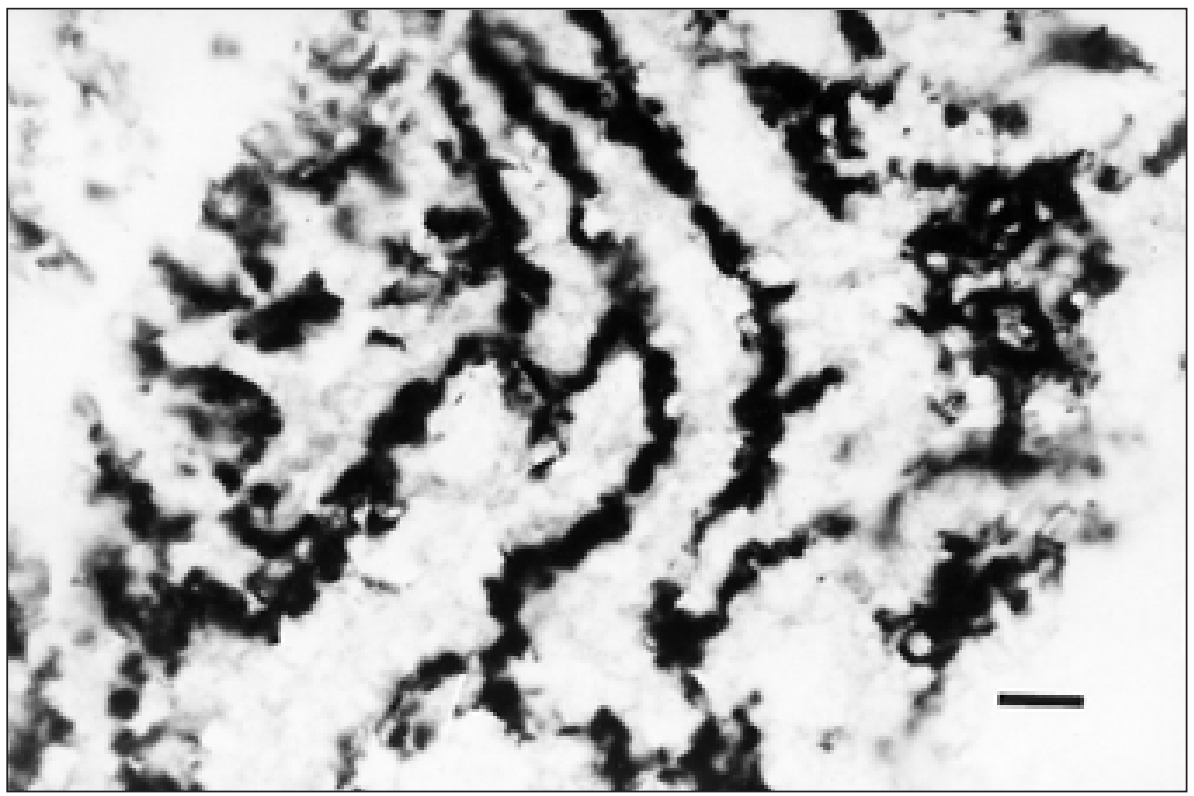

Fig. 2. Light micrograph of jejunal alkaline phosphatase activity in a $7 \mu \mathrm{m}$ cryostat section in experimental quails. The final reaction product is found in the brush border of the cells along the villus axis. Bar $=35 \mu \mathrm{m}$

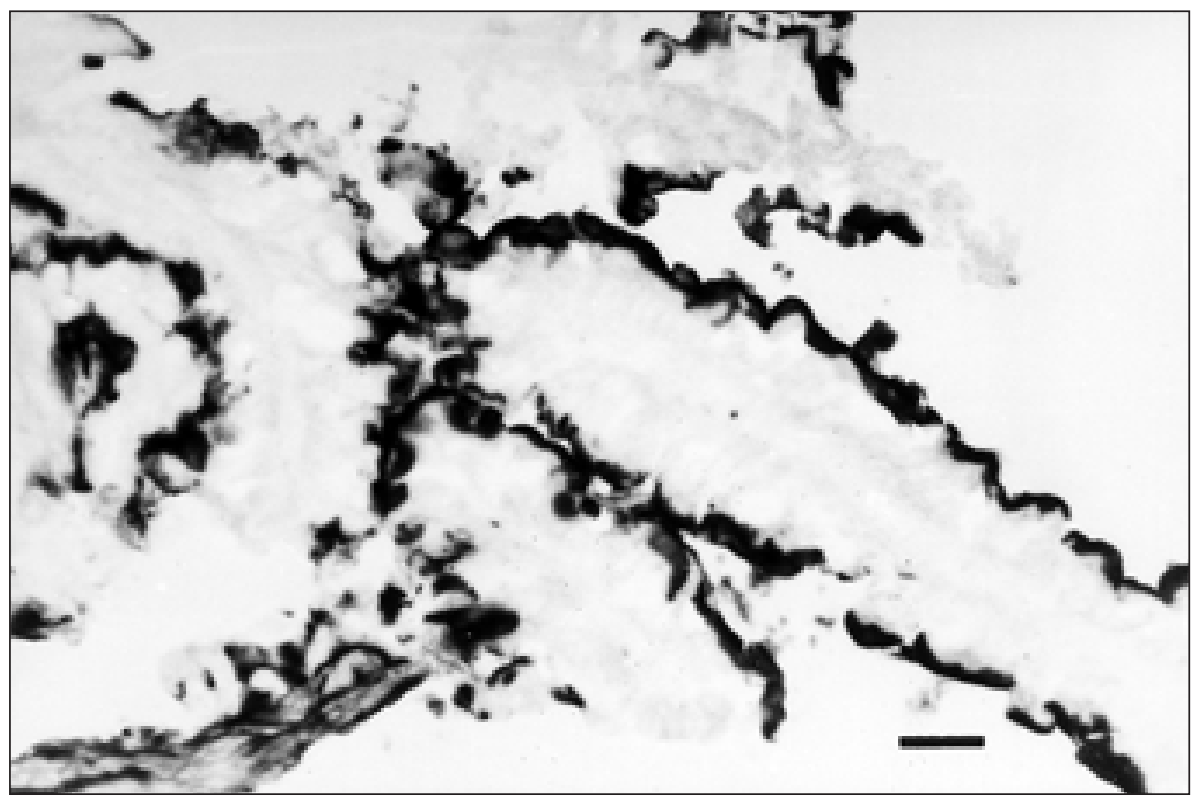

Fig. 3. Light micrograph of jejunal alkaline phosphatase activity in a $7 \mu \mathrm{m}$ cryostat section in control quails. The final reaction product is found in the brush border of the cells along the villus axis. Bar $=35 \mu \mathrm{m}$ 